\title{
Nitrous oxide emissions from black soils under a continuous soybean cropping system in northeast China
}

\author{
W.W. Chen ${ }^{1,2}$, Y.Y. Wang ${ }^{1 *}$, Z.C. Zhao ${ }^{1}$, F. Cui ${ }^{2}$, J.X. Gu' ${ }^{2}$, X.H. Zheng ${ }^{2}$ \\ ${ }^{1}$ Northeast Institute of Geography and Agroecology, Chinese Academy of Sciences, Changchun 100029, \\ China ${ }^{2}$ State Key Laboratory of Atmospheric Boundary Layer Physics and Atmospheric Chemistry, Institute of \\ Atmospheric Physics, Chinese Academy of Sciences, Beijing 100029, China \\ Yiyong Wang, Northeast Institute of Geography and Agroecology, Chinese Academy of Sciences, Changchun, \\ 100029, China. *Corresponding author: wangyiyong@neigae.ac.cn
}

\begin{abstract}
A large number of natural wetlands in northeast China have been reclaimed as farmland in the last few decades, and soybean is the main rain-fed crop here. For the depth understanding of nitrous oxide $\left(\mathrm{N}_{2} \mathrm{O}\right)$ emission from reclaimed soybean fields, using static opaque chamber method, we conducted a four-year $\mathrm{N}_{2} \mathrm{O}$ flux measurement at two adjacent soybean fields cultivated after wetland drainage in 1987 and 1993, respectively, in the Sanjiang Plain of northeast China Using static opaque chamber method,. Both sites had two treatments including soybean cropped and bare soils (i.e., SF87, BS87, SF93 and BS93). The results showed that soil $\mathrm{N}_{2} \mathrm{O}$ emission from all of the plots was severely inhibited by the low temperature in winter (November to March), while a $\mathrm{N}_{2} \mathrm{O}$ emission pulse occurred during the spring thaw (April and May). Temporal variation of the $\mathrm{N}_{2} \mathrm{O}$ fluxes during the growing season varied over all the four years but was mainly affected by soil water-filled pore space (WFPS). Intense rainfall events increased the intensity and duration of $\mathrm{N}_{2} \mathrm{O}$ pulses during the growing season, and most high fluxes were occurred at WFPS $>45 \%$. The mean annual $\mathrm{N}_{2} \mathrm{O}$ emission from all treatments over four years was $4.8 \pm 1.2 \mathrm{~kg} \mathrm{~N} \mathrm{ha}^{-1}$ (ranges: 1.9-19.8), and one third of the emission originated from the spring-thaw. In addition, soybean growth did not increase $\mathrm{N}_{2} \mathrm{O}$ emissions during the growing season, which support the cancellation of $\mathrm{N}_{2} \mathrm{O}$ emission calculations from nitrogen fixed by legumes in the 2006 IPCC Guidelines for National Greenhouse Gas Inventories.
\end{abstract}

Keywords: Greenhouse gas, $\mathrm{N}_{2} \mathrm{O}$; spring-thaw, reclamation years, marshes, black soil, the Sanjiang Plain

\section{Introduction}

Nitrous oxide $\left(\mathrm{N}_{2} \mathrm{O}\right)$, a long-lived atmospheric trace gas with 298 times the global warming potential of carbon dioxide, contributes to climate change and ozone depletion (IPCC, 2007). The agricultural sector has been recognized as primarily responsible $(70 \%-80 \%)$ for global anthropogenic $\mathrm{N}_{2} \mathrm{O}$ emissions (Isermann, 1994). The $\mathrm{N}_{2} \mathrm{O}$ emission from agricultural soils, mainly produced by 
the soil microbial processes of nitrification and denitrification, is estimated to be $0.11-6.3 \mathrm{Tg} \mathrm{N} \mathrm{yr}^{-1}$ (Mosier et al., 1998; Bouwman et al., 2002). Studies have shown the large uncertainty concerning the spatio-temporal variation in soil $\mathrm{N}_{2} \mathrm{O}$ fluxes, which are strongly dependent on crop type, field management, soil property and climate characteristics (Snyder et al., 2009; Desjardins et al., 2010; Reay et al., 2012; Cowan et al., 2014; Uzoma et al., 2015). Clarification of the processes and magnitude of $\mathrm{N}_{2} \mathrm{O}$ emissions from various agricultural soils provides information to mitigate the multiple effects of atmospheric $\mathrm{N}_{2} \mathrm{O}$.

Nitrogen sources promote $\mathrm{N}_{2} \mathrm{O}$ production and emission from agricultural or vegetable soils (Snyder et al., 2009; Lu et al., 2010; Mu et al., 2013). With the ability to fix and store nitrogen, a soybean field may be a contributor to agricultural $\mathrm{N}_{2} \mathrm{O}$ emission. In China, soybean fields cover approximately $8.3 \%$ of the total arable land (National Bureau of Statistics of China, 2006), indicating their importance in the regional $\mathrm{N}_{2} \mathrm{O}$ budget. To date, soil $\mathrm{N}_{2} \mathrm{O}$ fluxes under cropping systems that require a large amount of mineral $\mathrm{N}$ fertilizer and manures (e.g., wheat, corn and rice) have been intensively documented (Liu et al., 2011), but only limited information is available for soybean and legume crops. The $\mathrm{N}_{2} \mathrm{O}$ fluxes from a soybean field have been reported for a spring-sown soybean field in northeast China (Chen et al., 2000; Zhang et $a l ., 2000)$ and a summer-sown soybean field in eastern China (Hu et al., 2010). The effects of enhanced UV-B radiation, straw addition, nitrogen fixation and production of $\mathrm{N}_{2} \mathrm{O}$ emissions from soybean and legume fields have also been studied (Zhong et al., 2009; Hu et al., 2010). However, these studies are conducted over the short term (i.e., from a few days to a growing season) and information about long-term $\mathrm{N}_{2} \mathrm{O}$ fluxes from soybean fields is still lacking.

More than $40 \%$ of the soybean fields in China are centralized in northeast China (i.e., Heilongjiang,
Jilin and Liaoning provinces and parts of the Inner Mongolia Autonomous Region) (National Bureau of Statistics of China, 2006). This region is one of three black earth terrains in the world. Fertile soils provide abundant carbon and nitrogen substrate for $\mathrm{N}_{2} \mathrm{O}$ production in addition to meeting the demand of crop growth. Most soybean fields in the Sanjiang Plain of northeast China have been reclaimed and cultivated from the natural wetlands over the past few decades. Reporting the changes in greenhouse gases resulting from wetland reclamation are explicitly required in the IPCC inventory guidance. Studies have shown that soil properties, nutrient cycles, microbial activities and soybean growth are closely associated with the number of years of cultivation (Song et al., 2004). These activities may affect the processes of $\mathrm{N}_{2} \mathrm{O}$ emission involving its production and transport from the soil to the atmosphere.

This study presents four years of data on $\mathrm{N}_{2} \mathrm{O}$ emissions from black soils under a continuous soybean cropping system in the Sanjiang Plain of northeast China. Using the static opaque chamber and gas chromatography methods, we measured $\mathrm{N}_{2} \mathrm{O}$ fluxes in-situ from 2002-2006 at two soybean fields that differed in the number of years since reclamation. Our primary objectives were to investigate temporal variations in $\mathrm{N}_{2} \mathrm{O}$ fluxes, the relationships between $\mathrm{N}_{2} \mathrm{O}$ fluxes and environmental factors and the relationship of these emissions with soybean growth.

\section{Materials and Methods}

\subsection{Study site}

The study was located at the Sanjiang Mire-Wetland Experimental Station (WWES, 47 $35^{\prime} \mathrm{N}, 133^{\circ} 31^{\prime}$ E; $55 \mathrm{~m}$ a.s.1.) of the Chinese Ecosystem Research Network, in the Sanjiang Plain of eastern Heilongjiang 
Province, China. The elevation of the study sites is approximately 55-61 meter msl with a gradient of $1 / 5000-1 / 10000$. The local climate is a temperate continental monsoon of a seasonally frozen zone. The mean annual temperatures are $1.6-1.9{ }^{\circ} \mathrm{C}$ with a mean January temperature ranging from -21 to $-18{ }^{\circ} \mathrm{C}$ and July mean temperature of $21-22{ }^{\circ} \mathrm{C}$. The annual precipitation is $565-600 \mathrm{~mm}$, of which more than $60 \%$ falls from June to August, and the annual evaporation is $542-580 \mathrm{~mm}$. In this region, the growing season starts in May and ends in September; the remaining seven months comprise the non-growing season (from October to April of the following year). Because this is an area supporting a major upland crop, most soybean fields were reclaimed from marshy meadows in the Sanjiang Plain. The black soil had the following properties: a mean organic carbon content of $2.0 \%$ $(0-20 \mathrm{~cm})$, a mean $\mathrm{pH}$ of $6.1(0-4 \mathrm{~cm})$, a mean bulk density of $1.0 \mathrm{~g} \mathrm{~cm}^{-3}(0-4 \mathrm{~cm})$ and a mean porosity of $0.62(0-4 \mathrm{~cm})$.

\subsection{Experimental design}

Two adjacent soybean field sites with an area of 2.0 ha in WWES were selected for $\mathrm{N}_{2} \mathrm{O}$ flux measurements in situ. They have been successively cultivated from wetlands since 1987 and 1993, respectively. At each site, three paired plots including cropped soybean field and fallowed bare soil in the current year were randomly set in each year. Each plot (i.e., cropped soybean field and bare soil) was $4 \mathrm{~m}$ long and $4 \mathrm{~m}$ wide. Fallowed bare soils were implemented by removing soybean seed in their plots. Thus, four treatments were involved in this study, i.e., cropped soybean field under cultivated-year of 1987 (hereinafter referred to as SF87) and bare soil under cultivated-year of 1987 (hereinafter referred to as BS87); cropped soybean field under cultivated-year of 1993 (hereinafter referred to as SF93) and bare soil under cultivated-year of 1993 (hereinafter referred to as BS93).

Soybean fields were cultivated under the local convention and were managed without irrigation. Synthetic fertilizer was applied once as a base fertilizer before sowing. Fallowed bare soils were implemented by removing soybean seed in their plots. In 2003, the fertilizer included $30 \mathrm{~kg} \mathrm{~N} \mathrm{ha}^{-1}$ of urea and

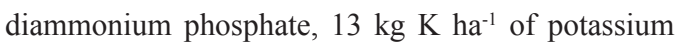
sulfate and $46 \mathrm{~kg} \mathrm{P} \mathrm{ha}^{-1}$ of diammonium phosphate. After 2004, we used $20 \mathrm{~kg} \mathrm{~N} \mathrm{ha}^{-1}$ and $14 \mathrm{~kg} \mathrm{~K} \mathrm{ha}^{-1}$ of Sakefu compound fertilizer (Sino-Arab Chemical Fertilizer Co. LTD, Qinhuangdao City, China) with proportions of N, P and K of $20 \%, 12 \%$ and $14 \%$ and $30 \mathrm{~kg}$ of superphosphate. From 2003-2006, soybeans (Glycine max L., Merr. SuiNong 10) were sown in the second half of May, sprouted around early June and harvested in late September. Soybean fields were weeded twice July and August. The soybean residues after harvesting were smashed by harvester and incorporated into soils $(\sim 30 \mathrm{~cm})$, but all plots were still covered with some soybean residues on the surface.

\subsection{Nitrous oxide measurements}

The $\mathrm{N}_{2} \mathrm{O}$ fluxes of the two soybean fields were measured from October 2002 to September 2006. During the growing period (May to September) of each year, the $\mathrm{N}_{2} \mathrm{O}$ flux measurements from four treatments (SF87, SF93, BS87 and BS93) were performed twice a week. During the non-growing season, only treatment SFE87 was used to measure $\mathrm{N}_{2} \mathrm{O}$ flux at a frequency of once or twice a month. During the spring thaw in 2004 (from end March to early May), we conducted flux measurements every day or every alternate day.

Static opaque chamber and gas chromatography techniques were applied to determine the fluxes of 
$\mathrm{CO}_{2}, \mathrm{CH}_{4}$ and $\mathrm{N}_{2} \mathrm{O}$ from the paddy fields (Zheng et al., 2008). The static chambers were made of stainless steel and consisted of three parts: a square base frame (length $\times$ width $\times$ height $=0.5 \mathrm{~m} \times 0.5 \mathrm{~m} \times 0.25 \mathrm{~m}$ ), a removable middle box (length $\times$ width $\times$ height $=$ $0.5 \mathrm{~m} \times 0.5 \mathrm{~m} \times 0.5 \mathrm{~m}$ ) and a removable top (length $\times$ width $\times$ height $=0.5 \mathrm{~m} \times 0.5 \mathrm{~m} \times 0.5 \mathrm{~m}$ ). The frames were inserted directly into the soil to a depth of 0.25 $\mathrm{m}$ and remained fixed during the entire observation period. Three frames were set as spatial replicates for each treatment. The chamber tops were mounted onto the base frames during the gas sampling and were immediately removed after collection of the air samples. The removable middle box was only used to protect the vegetation when the height of vegetation was higher than $0.5 \mathrm{~m}$. A fan $(10 \mathrm{~cm}$ in diameter) was installed inside the top of each chamber to generate turbulence in the chamber closure during sampling. A Styrofoam coating on the outside of the chambers prevented an increase in the headspace air temperature.

Gas sample collections usually started at approximately 9:00 a.m. local time. The chambers were closed for $30 \mathrm{~min}$, and gas samples $(100 \mathrm{ml})$ were collected every 10 min using plastic syringes. To minimize any negative effects on soybean growth, wooden bridges were manually set around each frame for gas sampling. The $\mathrm{N}_{2} \mathrm{O}$ concentrations in the gas samples were analyzed by gas chromatography. The gas chromatograph (Agilent 6820, Shanghai, China) was equipped with an electron capture detector (ECD) for the $\mathrm{N}_{2} \mathrm{O}$ analysis (Zheng et al., 2008). In the $\mathrm{N}_{2} \mathrm{O}$ analysis, the DN method, i.e., a method using dinitrogen $\left(\mathrm{N}_{2}\right)$ as the carrier gas (Zheng et al., 2008), was employed. The gas fluxes were calculated from changes in the initial rate of concentration change within the chambers' headspace; this was calculated from the initial slope of the non-linear regression of concentration against time. Zheng et al. (2008) found that the raw fluxes of $\mathrm{N}_{2} \mathrm{O}$ were biased due to crossinterference between $\mathrm{CO}_{2}$ and $\mathrm{N}_{2} \mathrm{O}$ in the air samples when using the DN method. They recommended a set of procedures to correct these biases. In this study, we corrected the raw $\mathrm{N}_{2} \mathrm{O}$ fluxes directly following the procedures recommended by Zheng et al. (2008). The detection limits for the $\mathrm{N}_{2} \mathrm{O}$ flux in our approach were $12 \mu \mathrm{g} \mathrm{N} \mathrm{m}^{-2} \mathrm{~h}^{-1}$, for a chamber height of $0.5 \mathrm{~m}$ with a sampling time of $30 \mathrm{~min}$ and an instrument precision of $1.5 \%$ for $\mathrm{N}_{2} \mathrm{O}$. When the chamber was extended to $1 \mathrm{~m}$ height to adapt to plant height, all of the values for these detection limits were doubled. The daily mean fluxes for each treatment were calculated by averaging the three replicates for each sampling day, and these were further integrated into the seasonal cumulative sums using a simple linear approach. Seasonal mean $\mathrm{N}_{2} \mathrm{O}$ fluxes were calculated by the balanced mean method instead of the arithmetic mean method because the daily $\mathrm{N}_{2} \mathrm{O}$ flux was not normally distributed. In the balanced mean method, the original $\mathrm{N}_{2} \mathrm{O}$ fluxes were transformed to the natural logarithm; the averages of transformed data were then calculated, and the averaged data were finally transposed exponentially.

\subsection{Auxiliary measurements}

Daily precipitation, air pressure and temperature data were obtained from the weather station at WWES. At each site, the soil temperature $\left(5 \mathrm{~cm},{ }^{\circ} \mathrm{C}\right)$ and soil moisture $(0-6 \mathrm{~cm}, \% \mathrm{v} / \mathrm{v})$ were manually measured during the sampling period when the soil was not frozen, with portable digital thermometers (JM 624, JinMing Instrument Co., Ltd., Tianjin, China) and a portable TDR probe (ThetaKit, Delta-T Devices, Cambridge, UK). The soil moisture was converted into water-filled pore space (WFPS) by dividing by the topsoil porosity $(0.62)$. 


\subsection{Data analysis}

The environmental variables (temperature, precipitation and soil moisture) and $\mathrm{N}_{2} \mathrm{O}$ emissions for the year, the growing season and the non-growing season were analyzed based on a year-round scale from October to September of the following year (i.e., 2002-2003, 2003-2004, 2004-2005 and 2005-2006). Plant growth effect was investigated by comparing $\mathrm{N}_{2} \mathrm{O}$ emissions between bare soil plots and cultivated plots, while cultivated year effect on $\mathrm{N}_{2} \mathrm{O}$ emission cannot be investigated because we do not have spatial replicates for specified cultivated soybean fields. The difference in $\mathrm{N}_{2} \mathrm{O}$ emission among treatments was analyzed using a one-way ANOVA with a Tukey's HSD test. Linear or non-linear regression analysis was used to assess the relationships between $\mathrm{N}_{2} \mathrm{O}$ flux and soil temperature and moisture. All statistical procedures were performed using the software packages SPSS 11.5 (SPSS Inc., Chicago, USA) and SigmaPlot 10.0 (SPSS Inc., Chicago, USA).

\section{Results}

\subsection{Environmental variables}

The mean annual air temperature $\left(1.7-2.6^{\circ} \mathrm{C}\right)$ during the sampling years 2002-2006 were close to the longterm average values for the same period $\left(2.2{ }^{\circ} \mathrm{C}\right.$ in 1990 to 2006) of the weather station at WWES (Table 1). The annual precipitations in 2003-2006 (544-561 $\mathrm{mm}$ ) were similar to the long-term average value (550 $\mathrm{mm})$ and $64 \%-90 \%$ of the annual precipitation fell from during May-August (Figure 1a). However, only half the multiyear average was recorded in 2002-2003 $(223 \mathrm{~mm})$, indicating an extreme drought that year. Intense rainfall events $(129 \mathrm{~mm})$ occurred in August 2003 , which accounted for approximately $60 \%$ of the annual precipitation. In addition, large inter-annual variations in monthly rainfall were observed during the growing season (Figure 1b).

The soil $(5 \mathrm{~cm})$ temperatures in the soybean fields ranged from $8.9^{\circ} \mathrm{C}$ to $30.5^{\circ} \mathrm{C}$ during the growing season, with an average value of $20.5 \pm 0.3^{\circ} \mathrm{C}$ (Figure 2 ). The topsoil WFPS varied from $14.6 \%$ to $85.4 \%$, with an average value of $51.6 \pm 1.8 \%$ (Figure 2). The mean WFPS from soybean fields was higher in 2006 than in other years (Table 1).

\subsection{Temporal variation of $\mathrm{N}_{2} \mathrm{O}$ fluxes}

The $\mathrm{N}_{2} \mathrm{O}$ fluxes at all sites ranged from 1 to $3456 \mu \mathrm{g}$ $\mathrm{N} \mathrm{m}^{-2} \mathrm{~h}^{-1}$ over the measurement period (Figs. 2 and 3), with a mean temporal coefficient of variation of $137 \pm$ 17\% (ranges: $62 \%-271 \%$ ). The $\mathrm{N}_{2} \mathrm{O}$ fluxes averaged $10 \pm 2 \mu \mathrm{g} \mathrm{N} \mathrm{m}^{-2} \mathrm{~h}^{-1}$ during the non-growing season and $36 \pm 11 \mu \mathrm{g} \mathrm{N} \mathrm{m}^{-2} \mathrm{~h}^{-1}$ during the growing season (Table 1)

Our data showed similar intra-annual trends in $\mathrm{N}_{2} \mathrm{O}$ fluxes among the treatments but different inter-annual variations for each treatment during the growing season. The minimum fluxes were generally recorded under dry conditions with soil WFPS $<20 \%$. Peaks in the $\mathrm{N}_{2} \mathrm{O}$ fluxes generally appeared after rainfall events but the strengths of the peak emissions were quite different within and between years. In 2006, the mean $\mathrm{N}_{2} \mathrm{O}$ flux $\left(234 \pm 128 \mu \mathrm{g} \mathrm{N} \mathrm{m}^{-2} \mathrm{~h}^{-1}\right)$ from all sites during the growing season have more than quadrupled compared to that in the other years. Very large $\mathrm{N}_{2} \mathrm{O}$ emissions from site BS93 were found with an average value of $1419 \pm 297 \mu \mathrm{g} \mathrm{N} \mathrm{m}^{-2}$ $\mathrm{h}^{-1}$ from the middle of August to the middle of September. Substantial $\mathrm{N}_{2} \mathrm{O}$ emission continued after soybean harvesting in October (Figure 3), while low $\mathrm{N}_{2} \mathrm{O}$ fluxes $\left(0-30 \mu \mathrm{g} \mathrm{N} \mathrm{m}^{-2} \mathrm{~h}^{-1}\right)$ were maintained throughout the frost period (November to March). The $\mathrm{N}_{2} \mathrm{O}$ emission in the fields increased after soil thawing and snowmelt, and the highest $\mathrm{N}_{2} \mathrm{O}$ flux was $252 \pm 207$ $\mu \mathrm{g} \mathrm{N} \mathrm{m} \mathrm{m}^{-2} \mathrm{~h}^{-1}$ 


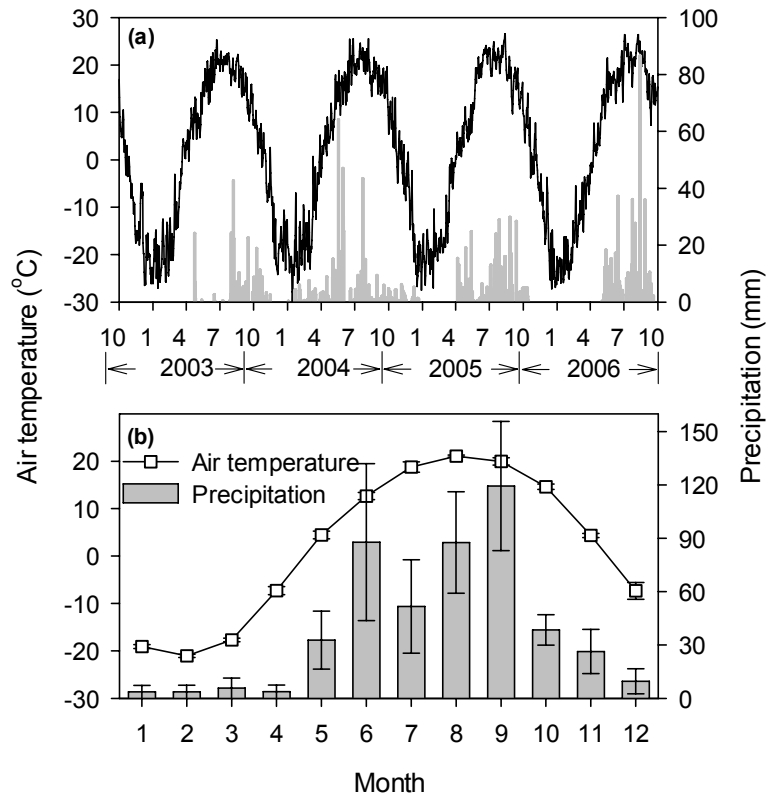

Figure 1. Mean daily (a) and monthly (b) air temperature and precipitation during the observation period.

Table 1 Mean $\mathrm{N}_{2} \mathrm{O}$ fluxes (MF), cumulative $\mathrm{N}_{2} \mathrm{O}$ emissions (CE), mean air temperature (AT), precipitation (Prec), mean soil temperature (ST) and soil water-filled pore space (WFPS) at four sites during the measured years

\begin{tabular}{|c|c|c|c|c|c|c|c|c|c|c|c|c|}
\hline \multirow{2}{*}{ Year } & \multirow{2}{*}{$\begin{array}{l}\text { Site } \\
\text { code }^{1}\end{array}$} & \multirow{2}{*}{$\begin{array}{l}\mathrm{AT} \\
\left({ }^{\circ} \mathrm{C}\right)\end{array}$} & \multirow{2}{*}{$\begin{array}{l}\text { Prec } \\
(\mathrm{mm})\end{array}$} & \multicolumn{2}{|c|}{ Non-growing season (NGS) ${ }^{2}$} & \multicolumn{4}{|c|}{$\begin{array}{c}\text { Growing season } \\
(\mathrm{GS})^{2}\end{array}$} & \multicolumn{2}{|c|}{ Annual $^{\dagger}$} & \multirow{2}{*}{$\begin{array}{c}\text { NGS } \\
\text { Contrib } \\
\text { ution } \\
(\%)\end{array}$} \\
\hline & & & & $\begin{array}{c}\text { MF } \\
\left(\mu \mathrm{g} \mathrm{m}^{-2} \mathrm{~h}^{-1}\right) \\
\end{array}$ & $\begin{array}{c}\mathrm{CE} \\
\left(\mathrm{kg} \mathrm{N} \mathrm{ha}^{-1}\right) \\
\end{array}$ & $\begin{array}{c}\text { MF } \\
\left(\mu \mathrm{g} \mathrm{m}^{-2} \mathrm{~h}^{-1}\right) \\
\end{array}$ & $\begin{array}{c}\mathrm{CE} \\
\left(\mathrm{kg} \mathrm{N} \mathrm{ha}^{-1}\right) \\
\end{array}$ & $\begin{array}{c}\text { ST } \\
\left({ }^{\circ} \mathrm{C}\right)^{3} \\
\end{array}$ & $\begin{array}{r}\text { WFPS } \\
(\%)^{4} \\
\end{array}$ & $\begin{array}{c}\text { MF } \\
\left(\mu \mathrm{g} \mathrm{m}^{-2} \mathrm{~h}^{-1}\right) \\
\end{array}$ & $\begin{array}{c}\mathrm{CE} \\
\left(\mathrm{kg} \mathrm{N} \mathrm{ha}^{-1}\right) \\
\end{array}$ & \\
\hline 2002 & SF87 & 1.7 & 223 & $8 \pm 1(0-52)$ & $0.7 \pm 0.1$ & $23 \pm 1(2-358)$ & $2.3 \pm 0.4$ & 18.2 & 46.0 & $33 \pm 6$ & $3.0 \pm 0.4$ & $23 \pm 6$ \\
\hline-2003 & SF93 & & & & & $15 \pm 1(2-143)$ & $1.2 \pm 0.1$ & 20.6 & 41.8 & & & \\
\hline \multirow{4}{*}{$\begin{array}{l}2003 \\
-2004\end{array}$} & SF87 & 1.9 & 561 & $15 \pm 1(1-309)$ & $1.1 \pm 0.2$ & $14 \pm 1(3-400)$ & $3.1 \pm 0.8$ & 20.4 & 39.6 & $39 \pm 13$ & $4.2 \pm 1.3$ & $26 \pm 9$ \\
\hline & BS87 & & & & & $15 \pm 1(1-1221)$ & $4.0 \pm 0.1$ & 21.2 & 39.8 & & & \\
\hline & SF93 & & & & & $10 \pm 1(1-792)$ & $2.4 \pm 0.5$ & 21.2 & 30.6 & & & \\
\hline & BS93 & & & & & $9 \pm 1(1-302)$ & $1.6 \pm 0.1$ & 20.9 & 32.4 & & & \\
\hline \multirow{4}{*}{$\begin{array}{l}2004 \\
-2005\end{array}$} & SF87 & 2.6 & 544 & $6 \pm 1(0-665)$ & $2.0 \pm 1.0$ & $26 \pm 1(2-226)$ & $1.6 \pm 0.3$ & 21.2 & 43.5 & $48 \pm 10$ & $3.6 \pm 1.3$ & $56 \pm 10$ \\
\hline & BS87 & & & & & $16 \pm 1(4-111)$ & $1.6 \pm 0.1$ & 22.2 & 45.6 & & & \\
\hline & SF93 & & & & & $15 \pm 1(4-93)$ & $1.0 \pm 0.1$ & 21.1 & 34.0 & & & \\
\hline & BS93 & & & & & $24 \pm 1(6-190)$ & $1.2 \pm 0.2$ & 20.8 & 36.4 & & & \\
\hline \multirow{4}{*}{$\begin{array}{l}2005 \\
-2006\end{array}$} & SF87 & 2.0 & 554 & $11 \pm 1(2-55)$ & $0.6 \pm 0.1$ & $44 \pm 1(6-156)$ & $2.5 \pm 0.2^{\mathrm{c}}$ & 19.0 & 45.5 & $41 \pm 6$ & $3.1 \pm 0.2$ & $19 \pm 2$ \\
\hline & BS87 & & & & & $74 \pm 1(11-515)$ & $4.1 \pm 0.5^{\mathrm{b}}$ & 19.4 & 45.0 & & & \\
\hline & SF93 & & & & & $67 \pm 1(8-1057)$ & $4.7 \pm 0.7^{\mathrm{b}}$ & 20.0 & 52.9 & & & \\
\hline & BS 93 & & & & & $158 \pm 1(8-3456)$ & $19.2 \pm 2.4^{\mathrm{a}}$ & 20.3 & 51.6 & & & \\
\hline \multirow{2}{*}{$\begin{array}{c}2002 \\
-2006^{5}\end{array}$} & SF87 & & & & $\begin{array}{c}1.1 \pm 0.3 \\
(58 \%)\end{array}$ & & $\begin{array}{c}2.4 \pm 0.3 \\
(26 \%)\end{array}$ & & & & $\begin{array}{c}3.5 \pm 0.3 \\
(16 \%)\end{array}$ & $\begin{array}{l}31 \pm 8 \\
(55 \%)\end{array}$ \\
\hline & SF93 & & & & & & $\begin{array}{c}2.3 \pm 0.8 \\
(73 \%) \\
\end{array}$ & & & & & \\
\hline
\end{tabular}

${ }^{1}$ The SF87, BS87, SF93 and BS93 represent the cropped soybean fields and bare soils drained and cultivated since 1987 and 1993 , respectively. ${ }^{2}$ The given data for MF and CE represent the means \pm standard error for three replicates, and the data in parentheses are their ranges. ${ }^{3}$ The mean of three replicates of topsoil $(5 \mathrm{~cm}) .{ }^{4}$ The mean of three replicates of topsoil $(0-6 \mathrm{~cm})$. The non-growing season is from October 1 to April 30 and the growing season is from May 1 to September 30. ${ }^{5}$ The given data are the four-year average of CE at SF87 and SF93, and the data in parentheses are the coefficients of variation of CE. 


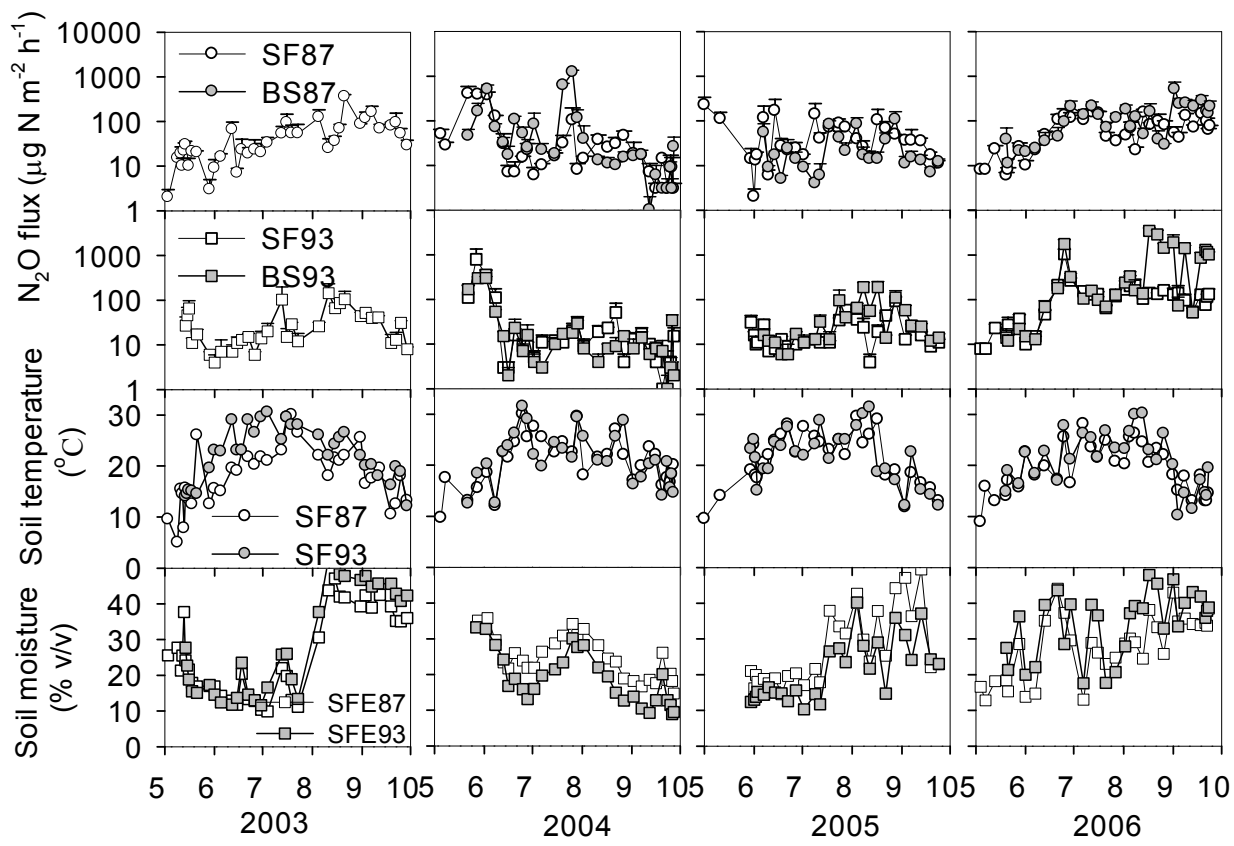

Figure 2. Seasonal variations of nitrous oxide fluxes ( \pm standard error), soil $(5 \mathrm{~cm})$ temperature and soil water-filled pore space (WFPS, 0-6 cm) at the investigated sites during the growing season in 2003-2006. Site codes are given in Table 1. Each point is the mean of three spatial replicates (i.e., chambers). The vertical axes of $\mathrm{N}_{2} \mathrm{O}$ flux represent a logarithmic scale.

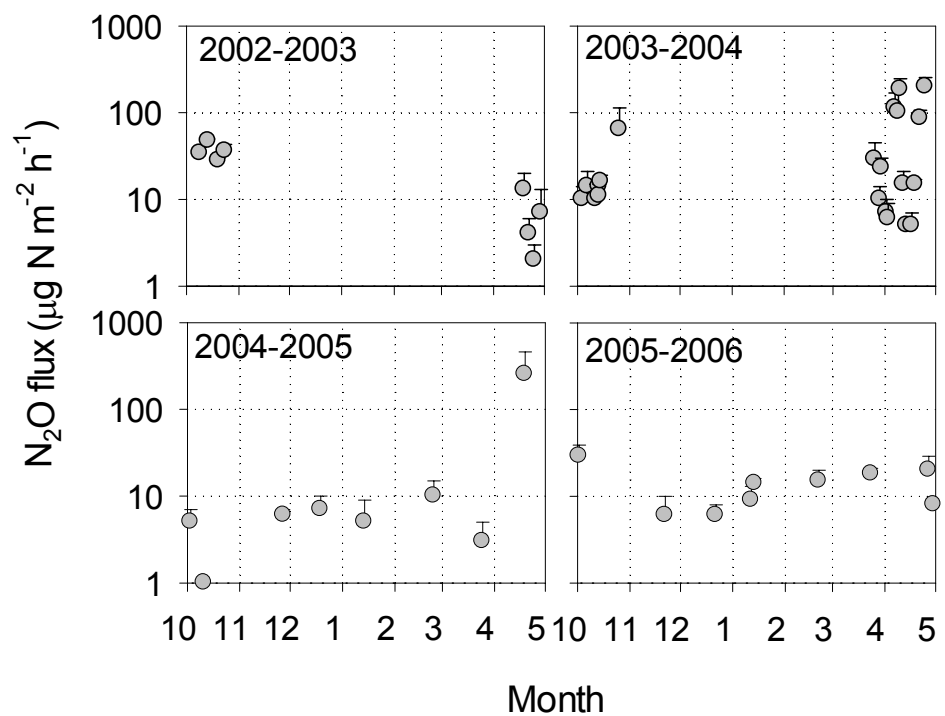

Figure 3. Nitrous oxide fluxes at SF87 during the non-growing season in 2002-2006. A logarithmic scale was used for the vertical axis (i.e., $\mathrm{N}_{2} \mathrm{O}$ flux). 


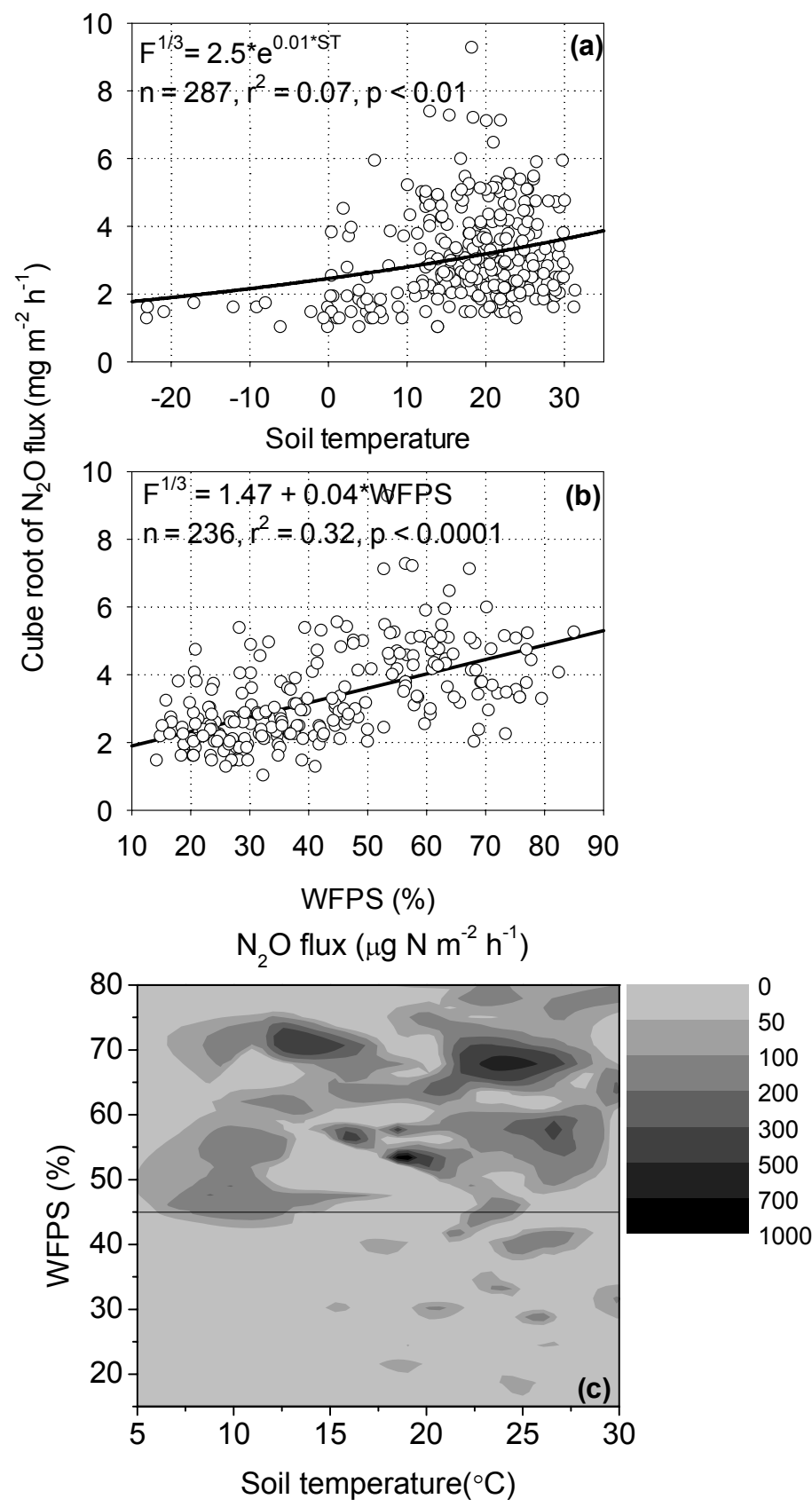

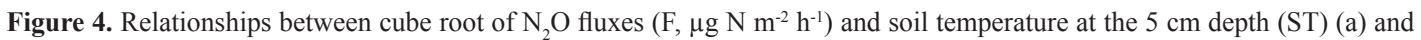
soil water-filled pore space at 0-6 cm depth (WFPS) (b); the distribution contour of $\mathrm{N}_{2} \mathrm{O}$ flux as a function of soil temperature and WFPS during the growing season. All data from SF87 and SF93 in the four years were used for the regression analysis. Each flux datum is the mean of three replicates. The black solid line in plot (c) indicates the value of $45 \%$ in WFPS. 


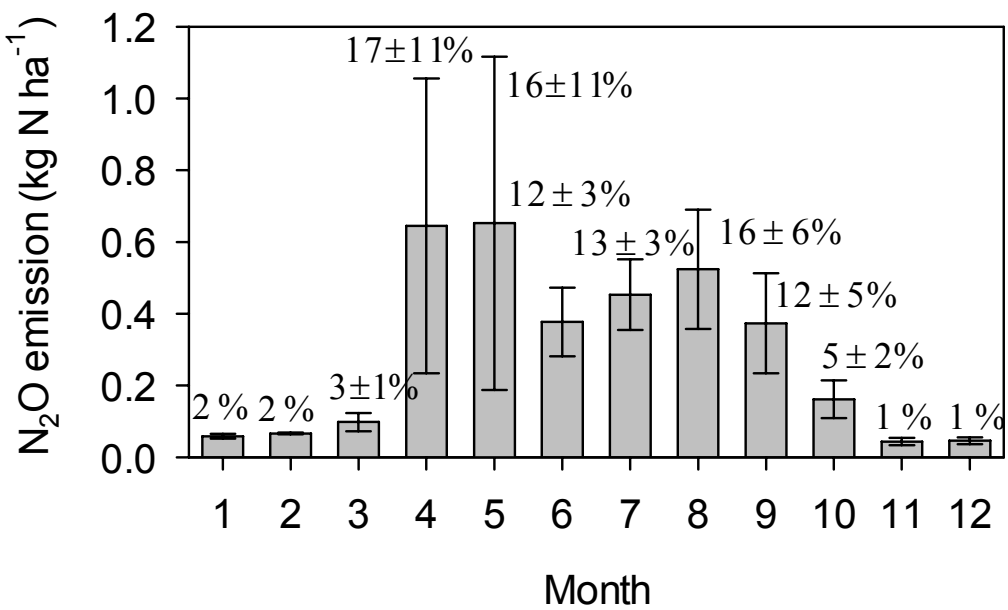

Figure 5. Monthly cumulative $\mathrm{N}_{2} \mathrm{O}$ emissions (bar) and contributions (number above bar) to annual $\mathrm{N}_{2} \mathrm{O}$ emission from SF87.

\subsection{Effects of soil temperature and water content on $\mathrm{N}_{2} \mathrm{O}$ fluxes}

Significantly positive correlations between the cubic root of daily $\mathrm{N}_{2} \mathrm{O}$ fluxes for all years and the soil temperature at $5 \mathrm{~cm}$ depth were demonstrated by an exponential equation (Figure 4a). Based on the regression equation, the $\mathrm{N}_{2} \mathrm{O}$ flux in soils with a temperature of $0{ }^{\circ} \mathrm{C}\left(14 \mu \mathrm{g} \mathrm{N} \mathrm{m}{ }^{-2} \mathrm{~h}^{-1}\right)$ was around the detection limit value of our method. Seasonal variations in the cubic root of daily $\mathrm{N}_{2} \mathrm{O}$ fluxes during the growing season were significantly determined by the soil WFPS at 0-6 $\mathrm{cm}$ depth (Figure 4b). Changes in the daily mean WFPS explained $32 \%$ of the variation in the cubic root $\mathrm{N}_{2} \mathrm{O}$ fluxes. The contour distribution plot indicates that high soil temperature and WFPS promoted $\mathrm{N}_{2} \mathrm{O}$ emission and most high fluxes were observed at WFPS $>45 \%$ (Figure $4 \mathrm{c}$ ).

\subsection{Annual $\mathrm{N}_{2} \mathrm{O}$ budget}

The annual $\mathrm{N}_{2} \mathrm{O}$ emission at $\mathrm{SF} 83$ over four years varied from 3.0 to $4.6 \mathrm{~kg} \mathrm{~N}^{-1}$, with $19 \%-56 \%$ (average: $31 \pm 8 \%$ ) of $\mathrm{N}_{2} \mathrm{O}$ fluxes occurring during the non-growing season (October to April) (Table 1). The $\mathrm{N}_{2} \mathrm{O}$ emission during the spring thaw period (April and May) contributed approximately one third of the annual magnitude while that in the frost period (November to March) only accounted for $9 \%$ of the annual emission (Fig. 5). Applying the $\mathrm{N}_{2} \mathrm{O}$ fluxes during the non-growing season at $\mathrm{SF} 83$ to the other sites, the annual $\mathrm{N}_{2} \mathrm{O}$ emission from black soils under soybean systems ranged from 1.9 to $19.8 \mathrm{~kg}$ $\mathrm{N} \mathrm{ha}^{-1}$ with an average of $4.8 \pm 1.2 \mathrm{~kg} \mathrm{~N} \mathrm{ha}^{-1}$ from 2002-2006. The total $\mathrm{N}_{2} \mathrm{O}$ emission was estimated at $0.03 \pm 0.01 \mathrm{Gg}$ in northeast China based on the mean annual $\mathrm{N}_{2} \mathrm{O}$ emission and the area of all the legumes cultivation (6.04 million hectares) in 2005. 
There were no significant differences in cumulative $\mathrm{N}_{2} \mathrm{O}$ emission during the growing season among different soybean fields and fallowed-bare soils when considering the overall data for the four years (Table 1).

\section{Discussion}

\subsection{Effects of soil temperature and water content on $\mathrm{N}_{2} \mathrm{O}$ fluxes}

Nitrous oxide fluxes from upland soils are closely linked to the available nitrogen substrates, organic carbon and environmental variables, such as the soil water content and temperature (Mosier et al., 1998; Snyder et al., 2009). Soybean fields in northeast China are usually fertilized once at less than $30 \mathrm{~kg}$ $\mathrm{N} \mathrm{ha}^{-1}$. Though nitrogen input increased the soil $\mathrm{N}_{2} \mathrm{O}$ production (Liu et al., 2010), obvious $\mathrm{N}_{2} \mathrm{O}$ emissions were not observed following such a minor addition of $\mathrm{N}$ via fertilization of the topsoil. Therefore, the combination of soil temperature and water content may dominate the seasonality of $\mathrm{N}_{2} \mathrm{O}$ fluxes due to their effects on $\mathrm{N}_{2} \mathrm{O}$ production and transport.

Freeze-thaw events have been shown to significantly affect $\mathrm{N}_{2} \mathrm{O}$ fluxes in different ecosystems (Teepe et al., 2001; Groffman et al., 2006; Pelster et al., 2012). The investigated soybean fields in the Sanjiang Plain belong to the seasonal-freeze-thaw region. The weak $\mathrm{N}_{2} \mathrm{O}$ emission from fallowed soils $\left(<30 \mu \mathrm{g} \mathrm{N} \mathrm{m}^{-2} \mathrm{~h}^{-1}\right)$ during the frost period lasted for five months (Figure 3). Generally, denitrification would stop at a lower temperature limit of $0-3{ }^{\circ} \mathrm{C}$ (Nyborg et al., 1997). Thus, this level of $\mathrm{N}_{2} \mathrm{O}$ emission from the investigated fields was caused by the inhibition of microbial activity at extremely low temperature (i.e., $-3{ }^{\circ} \mathrm{C}$ to $-17{ }^{\circ} \mathrm{C}$ fro the monthly average) and the difficulty of gas diffusion from freezing of the moist soil.

Vigorous $\mathrm{N}_{2} \mathrm{O}$ emissions from soybean fields occurred during the spring thaw in April and May
(Figure 3), which is similar to the pulses of $\mathrm{N}_{2} \mathrm{O}$ emission in forests, grasslands and agricultural soils (Mosier et al., 1993; Teepe et al., 2001; Groffman et al., 2006). Denitrification in the topsoil has been found to contribute to the temporal increase in soil $\mathrm{N}_{2} \mathrm{O}$ production during this period (Nyborg et al., 1997). First, the thawing of frozen surface soil could create water saturated conditions ideal for denitrification. Second, nutrients were released from dead soil microorganisms or became available with the disruption of aggregates. This process provided more nitrate in the form of $\mathrm{N}_{2} \mathrm{O}$ reaction substrates. Third, the freeze-thaw transition may have enhanced soil microbial activity, accelerating the rate of reaction (Nyborg et al., 1997). Furthermore, nitrification of ammonium in non-frozen subsoil might have been a possible source of $\mathrm{N}_{2} \mathrm{O}$ during topsoil thaw (Teepe et al., 2001).

When temperature was not a limiting factor, the soil water content was important to $\mathrm{N}_{2} \mathrm{O}$ fluxes during the frost-free period (Cai et al., 2013). The soils planted with soybean were weak sources of $\mathrm{N}_{2} \mathrm{O}$ under dry conditions, while significant $\mathrm{N}_{2} \mathrm{O}$ emissions were usually found following dry-wet transitions and intense rainfalls. Observation of these phenomena agrees with previous studies in which $\mathrm{N}_{2} \mathrm{O}$ fluxes shortly after rainfalls were several fold greater than those under continuously aerobic conditions, especially in arid and semiarid regions (Galbally et al., 2008). Soil water content in WFPS below $25 \%$ was unfavorable to soil $\mathrm{N}_{2} \mathrm{O}$ production (Figure $4 \mathrm{~b}$ ), but we found a threshold value of WFPS at $45 \%$ for significantly higher $\mathrm{N}_{2} \mathrm{O}$ emission occurrence (Figure 4c). On the one hand, wetting dry soil produced anaerobic conditions for denitrification and improved microbial growth and activity where suitable water conditions prevailed (Dobbie and Smith, 2003); on the other hand, available $\mathrm{C}$ and $\mathrm{N}$ substrates were released through wetting and drying cycles (Priemé 
and Christensen, 2001). Moreover, the $\mathrm{N}_{2} \mathrm{O}$ produced in the soil profile under aerobic conditions could also move into the atmosphere when rain fell. Our studies found that intense rainfall events increased the intensity and duration of $\mathrm{N}_{2} \mathrm{O}$ pulses during the growing season, especially after long-term drought. However, $\mathrm{N}_{2} \mathrm{O}$ fluxes following continuous rainfalls gradually decreased during the late growing season (Figure 2), which may have been caused by the decrease in soil mineral $\mathrm{N}$ content.

Large $\mathrm{N}_{2} \mathrm{O}$ fluxes $\left(>1000 \mu \mathrm{g} \mathrm{N} \mathrm{m}^{-2} \mathrm{~h}^{-1}\right)$ at site BS93 lasted approximately one month in August 2006 (Figure 2). The level of $\mathrm{N}_{2} \mathrm{O}$ emission was possibly induced by the optimum WFPS condition (70\%-80\%) for denitrification and the high soil temperature (23$32^{\circ} \mathrm{C}$ ) favorable for microbial activity. Nevertheless, such high $\mathrm{N}_{2} \mathrm{O}$ emission in comparable environmental conditions did not always occur at other sites in other years (Figure 2), implicating large spatial-temporal variation in $\mathrm{N}_{2} \mathrm{O}$ fluxes from agricultural soils.

\subsection{Effect of soybean growth on soil $\mathrm{N}_{2} \mathrm{O}$ emission}

Soybean growth did not significantly affect soil $\mathrm{N}_{2} \mathrm{O}$ emission during the growing season (Table 1), which is consistent with observations in other agricultural systems (e.g., Huang et al., 2002; Almaraz et al., 2006). Additional $\mathrm{N}$ input at the beginning of the growing season would have been consumed with soybean growth and thereby decreased the soil mineral $\mathrm{N}$ content for $\mathrm{N}_{2} \mathrm{O}$ substrate. However, plant growth could also have been related to $\mathrm{N}_{2} \mathrm{O}$ production by enhancing denitrification or nitrification and providing better soil aeration for $\mathrm{N}_{2} \mathrm{O}$ transport from soil to the atmosphere compared to bare soils. Both sites may account for the low effect of soybean growth on $\mathrm{N}_{2} \mathrm{O}$ emission during the growing season. Legume growth-induced $\mathrm{N}_{2} \mathrm{O}$ emission often contributed to the $\mathrm{N}_{2} \mathrm{O}$ inventories due to nitrogen fixation, but calculation of $\mathrm{N}_{2} \mathrm{O}$ emission from nitrogen-fixing by legumes was cancelled in the 2006 IPCC Guidelines for National Greenhouse Gas Inventories (IPCC, 2006). In our results, insignificant differences in $\mathrm{N}_{2} \mathrm{O}$ emission during the growing season support that action. However, Yang and Cai et al. (2005) observed in a pot experiment that $\mathrm{N}_{2} \mathrm{O}$ emission from soybean treatments was six-folds than bare soils. The decomposition of roots and nodules was thought to stimulate $\mathrm{N}_{2} \mathrm{O}$ emission in pre-harvesting. Although this phenomenon was not observed in our field experiment, it indicates that dead root and litter may increase the amount of substrate for $\mathrm{N}_{2} \mathrm{O}$ production during the non-growing season, especially for the spring thaw.

\subsection{Magnitude of $\mathrm{N}_{2} \mathrm{O}$ emission}

Mean $\mathrm{N}_{2} \mathrm{O}$ fluxes $\left(9-74 \mu \mathrm{g} \mathrm{N} \mathrm{m}{ }^{-2} \mathrm{~h}^{-1}\right.$ ) during the growing season in the investigated plots fall within the range (11-255 $\mu \mathrm{g} \mathrm{N} \mathrm{m}{ }^{-2} \mathrm{~h}^{-1}$ ) reported from soybean field campaigns and pot experiments around the world (Chen et al., 2000; Yang and Cai et al., 2005; Almara et al., 2009; Hu et al., 2010). However, the maximum fluxes $\left(93-3456 \mu \mathrm{g} \mathrm{N} \mathrm{m}^{-2} \mathrm{~h}^{-1}\right)$ in the present study were outside the corresponding ranges (88-480 $\mu \mathrm{g} \mathrm{N} \mathrm{m}^{-2} \mathrm{~h}^{-1}$ ). The annual $\mathrm{N}_{2} \mathrm{O}$ emission in this study has more than doubled compared to the similar spring-sown soybean field $\left(2.0 \mathrm{~kg} \mathrm{~N} \mathrm{ha}^{-1}\right)$ in northeast China conducted by Chen et al. (2000). Furthermore, annual $\mathrm{N}_{2} \mathrm{O}$ emissions from our soybean fields are comparable with other rain-fed crops, such as wheat and maize in blackland (3.5-5.4 $\left.\mathrm{kg} \mathrm{N} \mathrm{ha}^{-1}\right)$, which need more nitrogen fertilizer input $(60-150 \mathrm{~kg}$ $\mathrm{N}^{-1} \mathrm{a}^{-1}$ per year) (Chen et al., 2000).

The stimulation of $\mathrm{N}_{2} \mathrm{O}$ emission during periods of spring thaw, dry-wet transition and intense rainfall in this study indicates the importance of estimation of the annual $\mathrm{N}_{2} \mathrm{O}$ emission from soybean soils in the cold 
temperate zone. As one of the area most influenced by global change, northeast China is characterized by a significant increasing trend of air temperature, especially in winter, and variations in the probability distribution features of extreme daily rainfall (Qian and Lin, 2005). These aspects could accelerate the cycles of freeze-thaw, dry-wet and rewetting. It suggests that the soil $\mathrm{N}_{2} \mathrm{O}$ source functions of a soybean field in northeast China may be enhanced by the increasing air temperature in winter and intense rainfall events in summer.

\section{Conclusions}

Based on long-term measurements, black soils were identified as high potential sources for atmospheric $\mathrm{N}_{2} \mathrm{O}$ under soybean cropping system in northeastern China. The annual $\mathrm{N}_{2} \mathrm{O}$ emission averaged to $4.8 \pm 1.2 \mathrm{~kg} \mathrm{~N}$ $\mathrm{ha}^{-1}$, in which approximately one-third was contributed by spring-thaw in April and May. Water-related events of dry-wet and intense-rainfall generated pulses of $\mathrm{N}_{2} \mathrm{O}$ emissions from rainfed soybean soils, and a threshold of $45 \%$ in soil water filled pore space was demonstrated for significant $\mathrm{N}_{2} \mathrm{O}$ emission. Compared with bare soils, the effect soybean growth on $\mathrm{N}_{2} \mathrm{O}$ emission during the growing season was not significant, supporting the cancellation of calculation of $\mathrm{N}_{2} \mathrm{O}$ emission from nitrogen-fixing by legumes in 2006 IPCC Guidelines for National Greenhouse Gas Inventories. Furthermore, our study indicates the soil $\mathrm{N}_{2} \mathrm{O}$ source functions in soybean fields will be strengthen considering the predicted winterwarming and rainfall-pattern changes in northeast China.

\section{Acknowledgements}

This work was financially supported by the National Natural Science Foundation of China (41205106, 41021004). We also thank the staff of the Sanjiang Mire-Wetland Experimental Station for their support of the field experiments and for providing meteorological data.

\section{Reference}

Almaraz, J.J., Mabood, F., Zhou, X., Madramootoo, C., Rochette, P., Ma, B., Smith, D.L. 2006. Carbon dioxide and nitrous oxide fluxes in corn grown under two tillage systems in southwestern Qebec. Soil Science Society of America Journal. 73, 113-119.

Bouwman, A.F., Boumans, L.J.M., Batjes, N.H. 2002. Emissions of $\mathrm{N}_{2} \mathrm{O}$ and $\mathrm{NO}$ from fertilized fields: summary of available measurement data. Global Biogeochemical Cycles. 16, doi: 10.1029/2001GB001812.

Cai, X.J., Ding, W.X., Luo, J.F. 2013. Nitrous oxide emissions from Chinese maize-wheat rotation systems: a 3 year field measurement, Atmospheric Environment. 65, 112-122.

Chen, G., Huang, B., Xu, H., Zhang, Y., Huang, G., Yu,, K., Hou, A., Du, R., Han, S., van Cleemput, O. 2000. Nitrous oxide emissions from terrestrial ecosystems in China. Chemosphere-Global Change Science. 2, 373-378.

Cowan, N.J., Famulari, D., Levy, P.E., Anderson, M., Reay, D.S., Skiba, U.M. 2014. Investigating uptake of $\mathrm{N}_{2} \mathrm{O}$ in agricultural soils using a highprecision dynamic chamber method. Atmospheric Measurement Techniques. 7, 4455-4462.

Desjardins, R.L., Pattey, E., Smith, W.N., Worth, D., Grant, B., Srinivasan, R., MacPherson, J.I., Mauder, M. 2010. Multiscale estimates of $\mathrm{N}_{2} \mathrm{O}$ emissions from agricultural lands. Agricultural and Forest Meteorology. 150, 817-824

Dobbie, K.E., Smith K.A. 2003. Nitrous oxide emission factors for agricultural soils in Great Britain: the impact of soil water-filled pore space and other controlling variables. Global Change Biology. 9, 204-218. 
Galbally, I.E., Kirstine, W.V., Meyer, C.P., Wang, Y.P. 2008. Soil-atmosphere trace gas exchange in semiarid and arid zones. Journal of Environmental Quality. 37, 599-607.

Groffman, P.M., Hardy, J.P., Driscoll, C.T., Fahey, T.J. 2006. Snowdepth, soil freezing, and fluxes of carbon dioxide, nitrous oxide and methane in a northern hardwood forest, Global Change Biology. 12, 1748-1760.

Hu, Z., Jiang, J., Chen, S., Liu, Q., Niu, C. 2010. Enhanced UV-B radiation reduced soil-soybean ecosystem respiration and nitrous oxide emissions. Nutrient Cycling in Agroecosystems. 87, 71-79.

Huang, Y., Jiao, Y., Zong, L., Wang, Y., Sass, R. 2002. Nitrous oxide emissions from the wheatgrowing season in eighteen Chinese paddy soils, an outdoor pot experiment. Biology and Fertility of Soils. 36, 411-417.

IPCC. 2006. 2006 IPCC Guidelines for National Greenhouse Gas Inventories, Prepared by the National Greenhouse Gas Inventories Programme, Eggleston H.S., Buendia L., Miwa K., Ngara T. and Tanabe K. (eds). Published, IGES, Japan.

IPCC. 2007. Climate Change. The Physical Science Basis. Contribution of Working Group I to the Fourth Assessment Report of the Intergovernmental Panel on Climate Change. Cambridge University Press, Cambridge, UK, New York, NY, USA, 539-542.

Isermann, K. 1994. Agriculture's share in the emission of trace gases affecting the climate and some cause-oriented proposals for sufficiently reducing this share. Environmental Pollution. 83, 95-111.

Liu, Y., Li, Y., Wan, Y., Chen, D., Gao, Q., Li, Y., Qin, X. 2011. Nitrous oxide emissions from irrigated and fertilized spring maize in semi-arid northern China. Agriclture, Ecosystems and Environment. 141, 287-295.
Lu, C., Ma, J., Chen, X., Zhang, X., Shi, Y., Huang, B. 2010. Effect of nitrogen fertilizer and maize straw incorporation on $\mathrm{NH}_{4}^{+}-\mathrm{N}_{-}{ }^{15}$ and $\mathrm{NO}_{3}-\mathrm{N}_{-}{ }^{15}$ accumulation in black soil of northeast China among three consecutive cropping cycles. Journal of Soil Science and Plant Nutrition. 10, 443-453.

Mosier, A., Kroeze, C., Nevison, C., Oenema, O., Seitzinger, S., van Cleemput, O. 1998. Closing the global $\mathrm{N}_{2} \mathrm{O}$ budget: nitrous oxide emissions through the agricultural nitrogen cycle, Nutrient Cycling in Agroecosystems. 52, 225-248.

Mu, Z.J., Huang, A.Y., Ni, J.P., Li, J.Q., Liu, Y.Y., Shi, S., Xie, D.T., Hatano R. 2013. Soil greenhouse gas fluxes and net global warming potential from intensively cultivated vegetable fields in southwestern China. Journal of Soil Science and Plant Nutrition. 13, 566-578.

National Bureau of Statistics of China. 2006. China Statistical Year book 2006. Beijing, China Statistic Press.

Nyborg, M., Laidlaw, J.W., Solberg, E.D., Malhi, S.S. 1997. Denitrificiation and nitrous oxide emissions from a Black Chernozemic soil during spring thaw in Alberta. Canadian Journal of Soil Science. 77, 153-160.

Pelster, D.E., Chantigny, M.H., Rochette, P., Angers, D.A., Laganière, J., Zebarth, B., Goyer, C. 2012. Crop residue incorporation alters soil nitrous oxide emissions during freeze-thaw cycles. Canadian Journal of Soil Science. 93, 415-425.

Priemé, A., Christensen, S. 2001. Natural perturbations, drying-wetting and freezingthawing cycles, and the emission of nitrous oxide, carbon dioxide and methane from farmed organic soils. Soil Biology Biochemistry. 33, 2083-2091.

Qian, W., Lin, X. 2005. Regional trends in recent precipitation indices in China. Meteorology and Atmospheric Physics. 90, 193-207. 
Reay, D.S., Davidson, E.A., Smith, K.A., Smith, P., Melillo, J.M., Dentener, F., Crutzen, P.J. 2012. Global agriculture and nitrous oxide emissions. Nature Climate Change. 2, 410-416.

Snyder, C.S., Bruulsema, T.W., Jensen, T.L., Fixen, P.E. 2009. Review of greenhouse gas emission from crop production systems and fertilizer management effects. Agriculture, Ecosystems and Environment. 133, 247-266.

Song, C., Wang, Y., Yan, B., Zhao, Z., Lou, Y. 2004. The changes of the soil hydrothermal condition and the dynamics of $\mathrm{C}, \mathrm{N}$ after the mire tillage. Chinese Journal of Environmental Science. 25, 150-154.

Teepe, R., Brumme, R., Beese, R. 2001. Nitrous oxide emissions from soil during freezing and thawing periods. Soil Biology Biochemistry. 9, 1269-1275.
Uzoma, K.C., Smith, W., Grant, B., Desjardins, R.L., Gao, X., Hanis, K., Tenuta, M., Goglio, P., Li C. 2015. Assessing the effects of agricultural management on nitrous oxide emissions using flux measurements and DNDC model. Agriculture, Ecoystems and Environment. 206, 71-83.

Yang, L., Cai, Z. 2005. The effect of growing soybean (GLycine max. L.) on $\mathrm{N}_{2} \mathrm{O}$ emission from soil. Soil Biology and Biochemistry. 37, 1205-1209.

Zhang, L., Pascal, B., Chen, G., Oswald, V.C. 2000. Nitrous oxide emission from herbicide-treated soybean. Biology Fertility of Soils. 32, 173-176.

Zheng, X., Mei, B., Wang, Y., Xie, B., Wang, Y., Dong, H., Xu, H., Chen, X., Cai, Z., Yue, J., Su, F., Zou, J. 2008. Quantification of $\mathrm{N}_{2} \mathrm{O}$ fluxes from soil-plant systems may be biased by the applied gas chromatograph methodology. Plant Soil. 311, 211-234.

Zhong, Z., Lemke, R., Neison, L.M. 2009. Nitrous oxide emissions associated with nitrogen fixation by grain legumes. Soil Biology and Biochemistry. 41, 2283-2291. 